\title{
Assessment of Factors Affecting Ephemeral Gully Development in Badland Topography: A Case Study at Garbheta Badland (Pashchim Medinipur, West Bengal, India)
}

\author{
Pravat Kumar Shit ${ }^{*}$, Gouri Sankar Bhunia ${ }^{2}$, Ramkrishna Maiti ${ }^{1}$ \\ ${ }^{1}$ Department of Geography \& Environment Management, Vidyasagar University, Medinipur, India \\ ${ }^{2}$ Rajendra Memorial Research Institutes of Medical Sciences (ICMR), Patna, Bihar, India \\ Email: *pravatgeo2007@gmail.com
}

Received October 11, 2012; revised December 5, 2012; accepted January 4, 2013

\begin{abstract}
Gully erosion in the Paschim Medinipur district of West Bengal, India has been an issue of anxiety, formed by the amputation of soil from narrow channels through the accretion of surface runoff. Here, we attempted to investigate the erosion variability of gully in a micro catchment area, and also scrutinized the gully cross-sectional areas as distinct components of gully volumes. Twelve gullies were randomly selected in different slopes. To determine the geometric growth of the gully dimensions and soil loss, the initial length of gully, the width of the gully and depth of respective gullies was monitored in different seasons. Univariate analysis was conducted to measure the association between gully head retreat and vegetation coverage, slope, rainfall volume and runoff contributing area. We found strong and significant relation between the slope of gully head and linear retreat in the pre monsoon $(\mathrm{p}<0.008)$ and post monsoon $(\mathrm{p}<$ $0.024)$ season respectively. Conversely, rainfall volume and gully head retreat showed a strong relationship in the pre monsoon $(r=0.80)$, monsoon $(r=0.66)$ and post-monsoon period $(r=0.94)$; while meager relationship was observed with rainfall intensity $(\mathrm{r}=0.06)$. Results also illustrated that the overall retreat of gully head had very strong and positive relationship with the runoff contributing area $(r=0.89, \mathrm{p}<0.001)$, and maximum gully erosion was observed in the monsoon period $(55.67 \%)$. These results indicate that slope, rainfall and runoff contributing area have a strong positive influence on gully erosion in Paschim Medinipur district, since the initiation of the gully.
\end{abstract}

Keywords: Gully Erosion; Gully Heads; Rainfall; Runoff Contributing Area; Sediment Yield

\section{Introduction}

Studies of soil erosion on local scales such as the individual gully system are an imperative subject of land degradation. Gully head morphology as the key factor of gully enlargement has also been well studied in worldwide $[1,2]$. Gully erosion is primarily caused and hastened by overland flow, influenced by runoff occurrence upslope. However, it is very tricky to gather comprehend- sive information incessantly, especially given the spatial condition and limited financial resources of a developing country. Previous studies [3-5] signified that gully erosion is often the key cause of sediment production.

Gully erosion has been an issue of anxiety in the Paschim Medinipur district of West Bengal, India. Gullies are formed by the amputation of soil from narrow channels through the accretion of surface runoff, tends to

${ }^{*}$ Corresponding author. fabricate more sediment loss than other forms of soil erosion such as overland flow [6-9]. Today, it is renowned as a major land degradation issue, causing both impacts on-site, through direct soil loss and off-site, through sediment deposition in downstream environments. The network of the gully has been developed by gully-head erosion [10,11], and it is a complex process with interactions and feedback mechanisms that are only conceptually and qualitatively understood $[12,13]$. Earlier researchers suggested that the gully-head retreat and gully development include upslope movement of the gully-head [14-16]. Though, previous workers reported that the mechanism of gully head erosion with more emphasis on the hydraulic shear by overland flow on the rim and on the vertical walls [11], the impact of splash from a plunge pool at the foot of a headcut [17], and mass wasting of walls [18]. However, the quantification of these processes is very difficult to attain and approximation in their predictions of where gullies begin and 
end are not well established. An additional problem in attempting to link short and long-term headcut erosion is the possibility of gully head bifurcation, which is a common process that can dramatically change the retreat process. Erosion problems crop up mainly from natural causes but their degree and severity are progressively more being attributed to man's unawareness and involuntary action [7]. However, long-term retreat rates often show negative-exponential trends [19], and linear ones have also been reported by Imeson and Kwaad [20]. Nevertheless, there is a need for short-term predictions of sediment yield, especially where gully heads retreat into agricultural fields. Recent soil erosion models, like WEPP [21], LISEM [22] and EUROSEM [23] predict the sediment yield from fields or catchments using event-based data considering the gully erosion.

In spite of technological advancement, gully erosion still remains a major problem in India. The yearly heavy rainfall has an enormous impact on developing landscape intensively eroded and dissected. Such landforms are creating deep gullies that cut into the soil. The gullies are spread and grow, until the soil is removed from the sloping ground. In the present study, we attempted to investigate the erosion variability of gully at Ganganir Danga, a micro catchment area of Paschim Medinipur district of West Bengal in India (Figure 1). We also scrutinized the gully cross-sectional areas as distinct components of gully volumes. Here, we focused, mainly on the headward erosion of the gully heads (gully headcut retreat). The field observations were carried out in the gully area during pre monsoon, monsoon and post monsoon season to depict the gullying patterns and to estimate the erosional activity of the same.

\section{Material and Method}

\subsection{Study Area}

The study work was conducted at Ganganir Danga of Garbheta block in Paschim Medinnipur district in West Bengal, India (lies between $22^{\circ} 51^{\prime} 18^{\prime \prime} \mathrm{N}-22^{\circ} 51^{\prime} 30^{\prime \prime} \mathrm{N}$

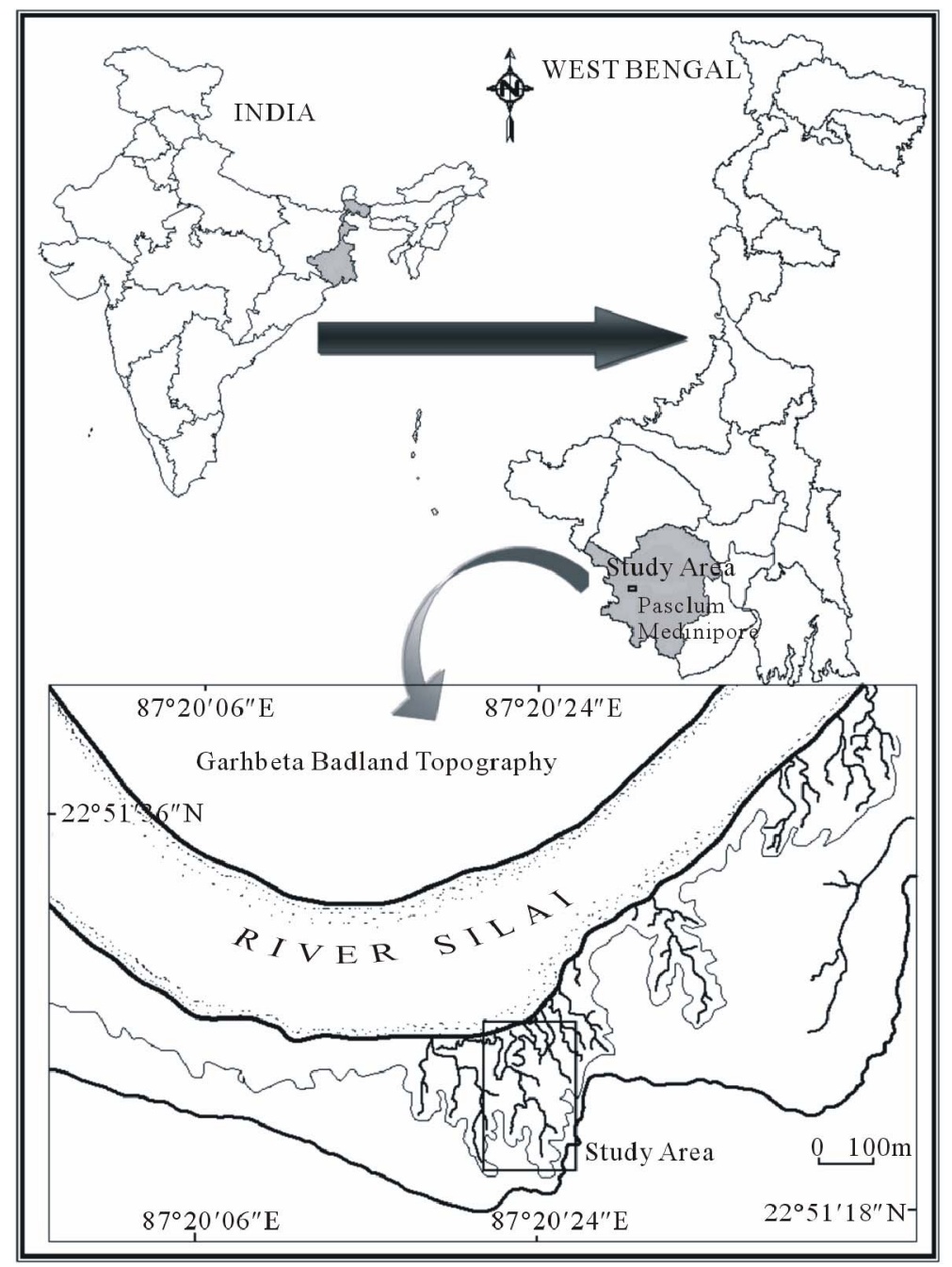

Figure 1. Location of the study area. 
latitude and $87^{\circ} 20^{\prime} 20^{\prime \prime} \mathrm{E}$ to $87^{\circ} 20^{\prime} 28^{\prime \prime} \mathrm{E}$ longitude). The area is covered by $3.5 \mathrm{~km}^{2}$ of Pleistocene lateritic upland, and is noted for spectacular ravine development on the concave right (northern) bank of river Silai [24] (Figure 1). The climate is tropical i.e., characterized by hot summer (maximum temperature $>39$ degree Celsius), cold winter (minimum $<10$ degree Celsius), abundant rainfall (1450 - $1560 \mathrm{~mm} /$ year) and humidity and the land surface of the study site is characterized by hard rock uplands, barren lateritic covered area and non-arable lands. Cross beddings and parallel beddings, composed of varied size grains and also shows possible fluctuation in erosional environment [25]. However, Geomorpho- logically, the study area is a part of the Chotonagpur flank and hills and is exemplified with mounds and rolling lands. The formation of Pali $(\sim 1000 \mathrm{~m})$ is portrayed by pebbly to coarse-grained micaceous sandstones medium to fine grained sandstones, and red and green coloured mudstones in the study area (Figure 2). The groundwater expansions and judicious organization of the surface water are imperative factors for endorsing current agriculture through high yielding and remunerative crops in the study site:

http://www.indianetzone.com/46/paschimmedinipur_dist rict.htm.

\subsection{Field Measurement and Monitoring}

In the present research, twelve gullies were randomly selected, four gullies in higher slope (above $50^{\circ}$ ), four gullies in middle slope $\left(40^{\circ}\right.$ to $\left.50^{\circ}\right)$ and four gullies in lower slope (below $40^{\circ}$ ) respectively. Measuring tapes and clinometers were used to determine length parameters and slope of the soil surface (immediately above and below the gully head) and of the channel bed below the gully head respectively (Figure 3 ). The drainage area was determined in the field by demarcating the area from where runoff could reach the gully head.

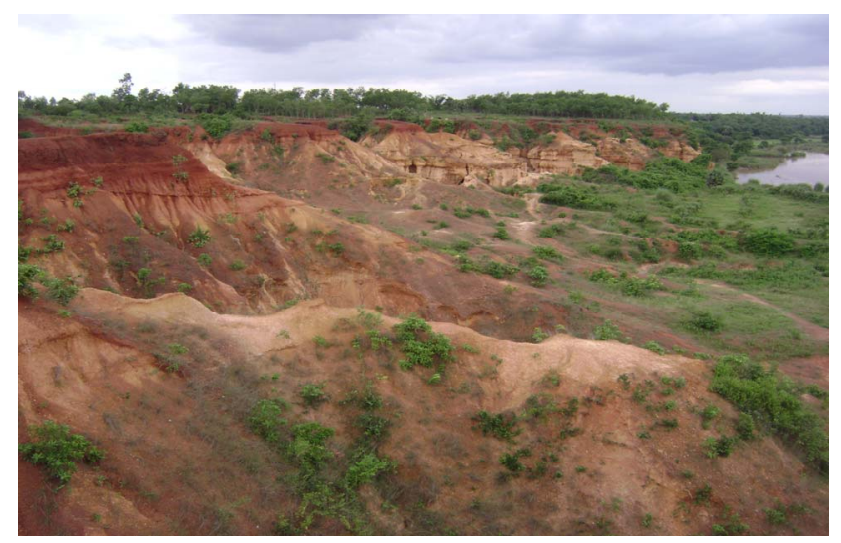

(a)
To determine the geometric growth of the gully dimensions and soil loss, initial length of gully, width of the gully and depth of respective gullies were noted. Subsequently, incremental changes of basic morphometric properties of gullies were measured (Figure 4). However, these properties were calculated at weekly intervals for 2010 and 2011 using a $30 \mathrm{~m}$ linen tape. Locally built ranging poles and $6 \mathrm{~cm} \times 24 \mathrm{~cm}$ pegs were used to compute the length, bed width and depth of the gullies, followed by the proposed method of Michael and Ojha, [26]. The gully top width, depths and bed width were monitored at the gully mouth, and gully head. Depths and width were measured repeatedly at $1 \mathrm{~m} \mathrm{spac}-$ ing interval, along the incised length of the gully. A tape was extended out across the gully to determine the top width at each interval to assess the length. Gully depth was measured vertically, e.g., from the tightly held tape to the gully bed via ranging pole. Rainfall within the catchment area was calculated by self recording rain gauge station during the pre monsoon, monsoon and post monsoon period.

Gully erosion is occurring due to hydraulic action of running water and it initiates with rills. Initially, the annual gully retreat rate was calculated, and subsequently the retreat of gully by individual storm events was assessed. Subsequently, the changes in the plans and dimensions of the gully heads have been used to estimate the amount of sediment volume eroded and the surface area affected (Figure 5).

Descriptive statistics were calculated of the study variables and univariate analysis was performed to delineate the statistical relationship between the variables in relation to gully head retreats. Simple linear regression analysis was done to measure the association between gully head retreat and each variable (e.g., rainfall, slope, and runoff contributing area) affecting the gully erosion in the study site. All the analysis was estimated at $<0.05$ significance level.

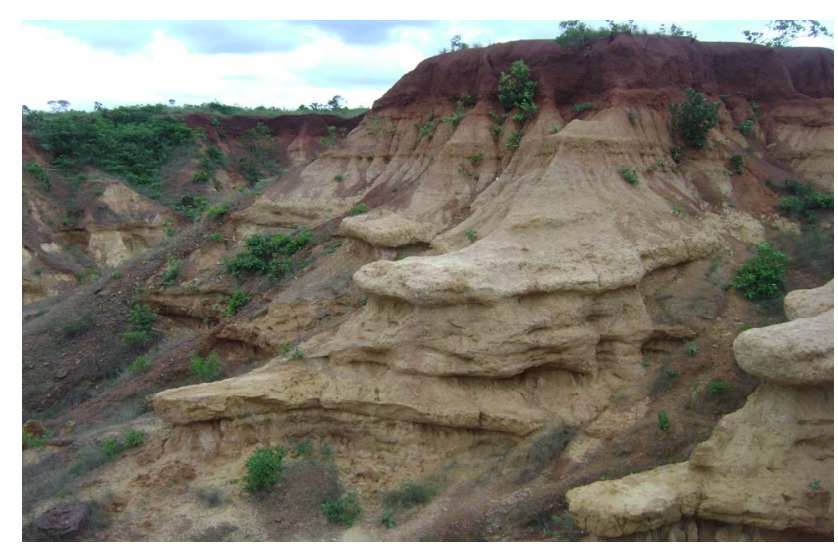

(b)

Figure 2. (a) Extensive red mudstone units; (b) Multistoried channel sandstones (at Garbheta, Paschim Medinipur). 


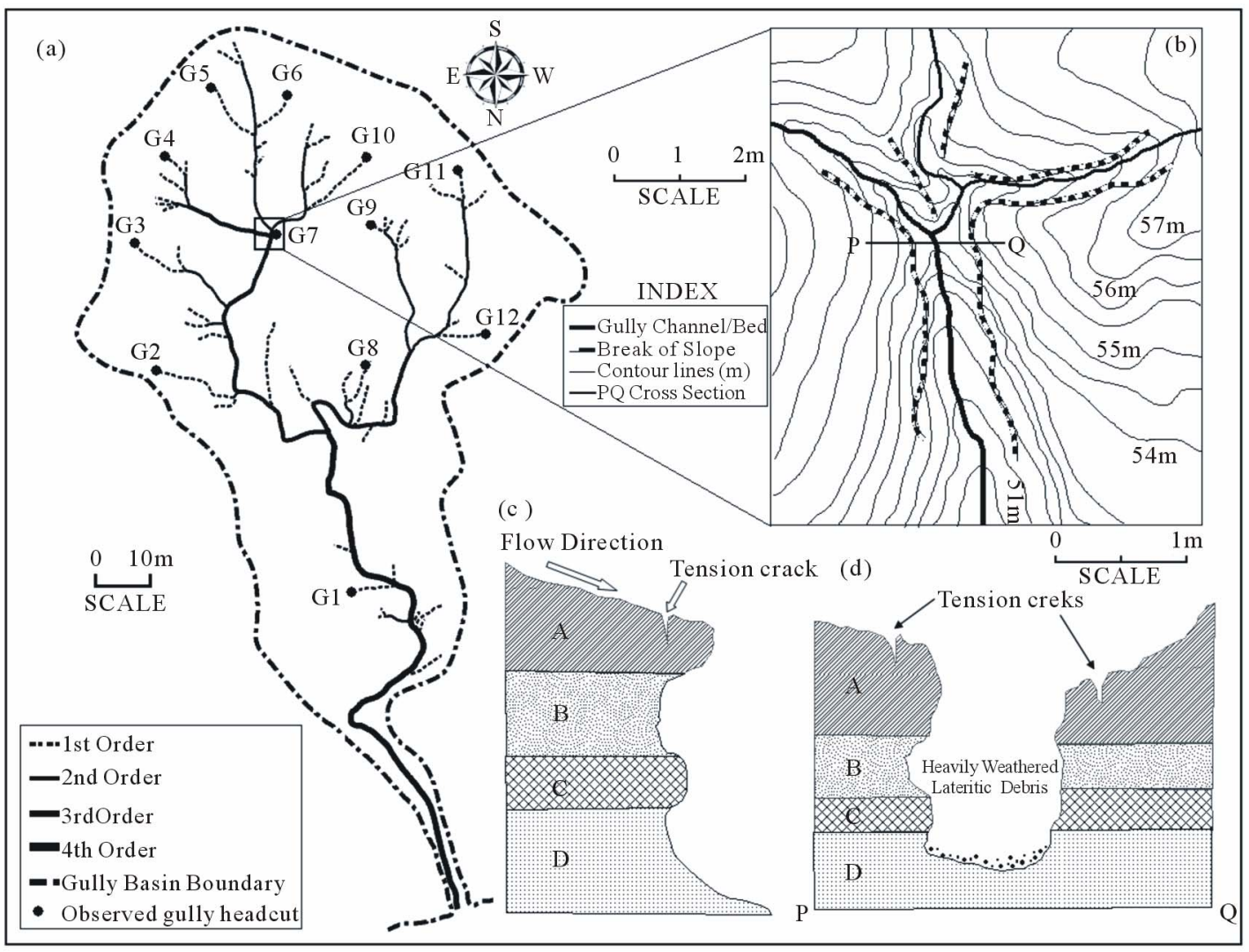

Figure 3. Gully erosion at Ganganir Danga. (a) Location of 12 gully headcut under study; (b) Details topographic information; and stratigraphic information (c) Plan view; (d) Cross section view of the main (G7) gully complex.

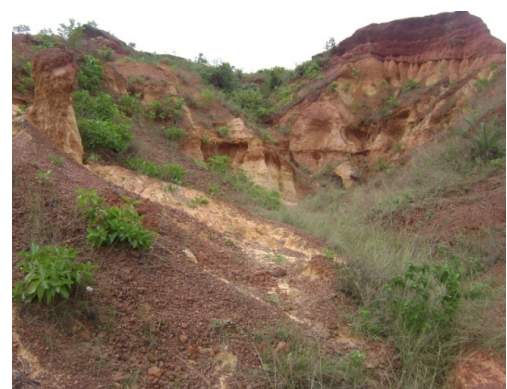

(a)

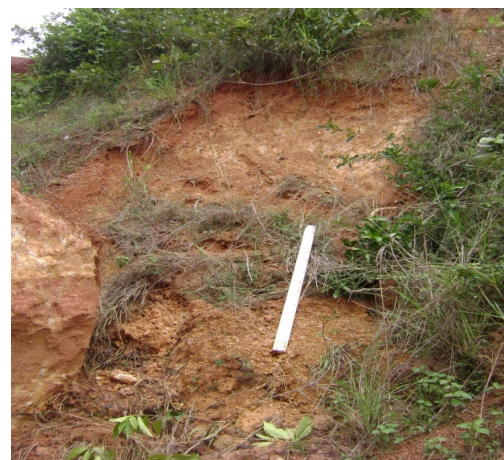

(d)

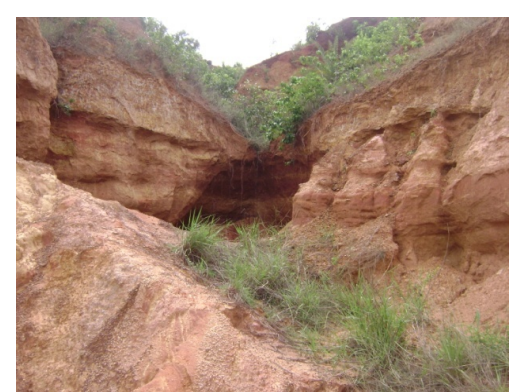

(b)

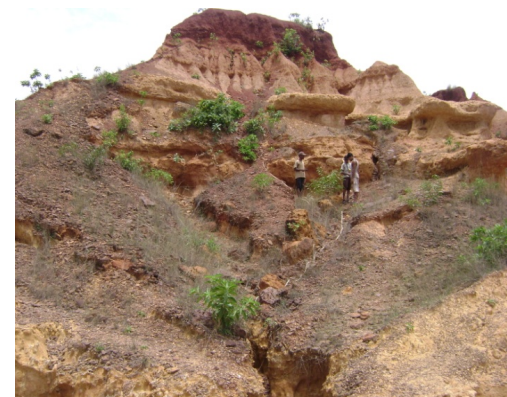

(e)

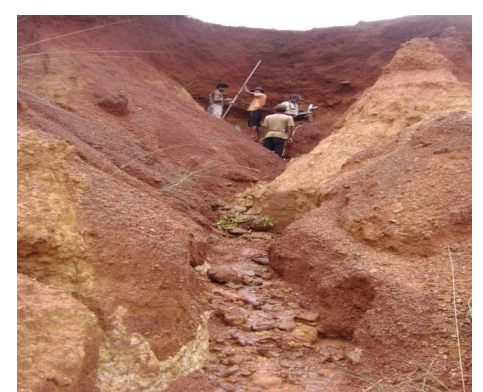

(c)

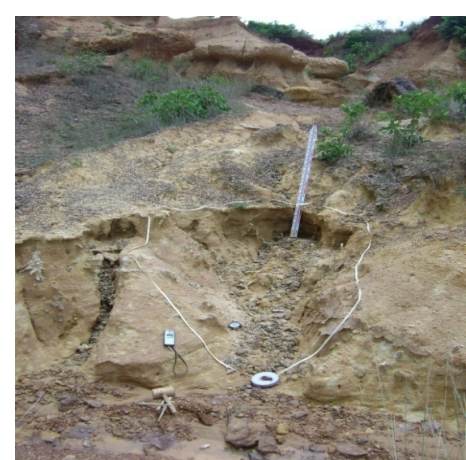

(f)

Figure 4. Gully head erosion. (a) Gully head and earth pillar; (b) Gully head undercutting due to seepage erosion; (c) Gullies head and wall measurement; (d) Gully head slumping; (e) Gullies head and length measurement; and (f) Gully head area measurement. 


\section{Result and Discussion}

\subsection{Slope and Gully Erosion}

The progression of gully-head and gully enlargement comprise upslope movement of the gully-head by overland flow on the rim and on the vertical walls. Though, earlier researcher studied the Relation between degree of gully erosion and slope gradient in worldwide [9,27-29]. However, in our study we measured the linear retreat of gully in respect to slope during the pre-monsoon, monsoon and post monsoon period (Table 1(a) and Figure 6). In the pre monsoon season the slope of the gully head varied from $30^{\circ}$ to $70^{\circ}$. The average slope of twelve of gully areas was $48.08^{\circ}$, with a standard deviation of \pm 13.80 . In the monsoon and post monsoon season, the slope of the gully head is ranged from $45^{\circ}-72^{\circ}$ (mean \pm standard deviation $57.75 \pm 9.57$ ) and $36^{\circ}-62^{\circ}$ (mean \pm standard deviation $47.83 \pm 8.62$ ) respectively. However, in our study area, we found strong and positive relation between the slope of gully head and linear retreat in the pre monsoon $(\mathrm{r}=0.46, \mathrm{p}<0.008)$ and post monsoon $(\mathrm{r}=$ $0.39, \mathrm{p}<0.024)$ season respectively. Conversely, moderate relationship was observed in the monsoon season $(\mathrm{r}=$ $0.30, \mathrm{p}<0.046)$.

\subsection{Rainfall and Gully Erosion}

Gully erosion in this area is occurring due to runoff con- centration and flows at a velocity adequate to disengage and transport soil particles. While peak flows from extreme rainfall causes substantial gully erosion, the protracted low flows resulting from a comprehensive wet period can also generate problems. In the present study, we estimated the relationship between linear retreat of gully head and rainfall volume in each gully area during the pre monsoon, monsoon and post monsoon period (Table 1(b) and Figure 7). During the pre monsoon

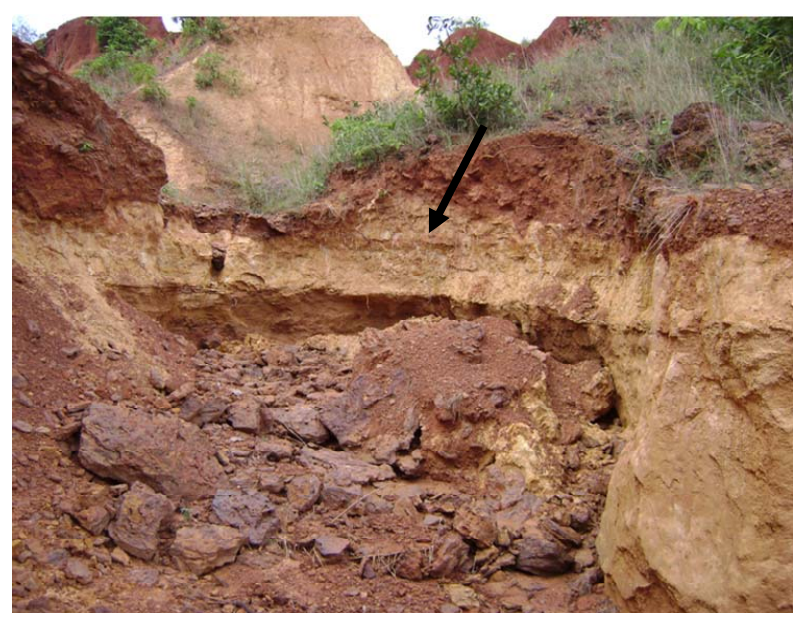

Figure 5. Collapsing the successively top bed rock in the gully head wall due to loss of cohesive force and under laying support, with the adding of moisture content.

Table 1. (a) Descriptive characteristics of twelve gully heads and their erosional parameters during different periods of time; (b) Descriptive characteristics of twelve gullies and their erosional parameters during different periods of time.

(a)

\begin{tabular}{|c|c|c|c|c|c|c|c|c|c|}
\hline \multirow[t]{2}{*}{ Descriptive characteristics } & \multicolumn{3}{|c|}{ Area (sq. m) } & \multicolumn{3}{|c|}{ Slope (Degree) } & \multicolumn{3}{|c|}{$\%$ of vegetation cover } \\
\hline & $\begin{array}{c}\text { Pre } \\
\text { Monsoon }\end{array}$ & Monsoon & $\begin{array}{c}\text { Post } \\
\text { Monsoon }\end{array}$ & $\begin{array}{c}\text { Pre } \\
\text { Monsoon }\end{array}$ & Monsoon & $\begin{array}{c}\text { Post } \\
\text { Monsoon }\end{array}$ & $\begin{array}{c}\text { Pre } \\
\text { Monsoon }\end{array}$ & Monsoon & $\begin{array}{c}\text { Post } \\
\text { Monsoon }\end{array}$ \\
\hline Mean & 279.71 & 280.88 & 282.49 & 48.08 & 57.75 & 47.83 & 3.21 & 4.92 & 7.73 \\
\hline Standard error & 22.02 & 22.15 & 22.12 & 3.98 & 2.76 & 2.49 & 0.33 & 0.48 & 0.57 \\
\hline Standard deviation & 76.27 & 76.72 & 76.62 & 13.80 & 9.57 & 8.62 & 1.14 & 1.68 & 1.97 \\
\hline Kurtosis & -0.42 & -0.40 & -0.42 & -0.94 & -1.55 & -1.01 & -1.14 & -0.80 & -0.41 \\
\hline Skewness & 0.58 & 0.60 & 0.60 & 0.66 & 0.14 & 0.27 & 0.60 & 0.69 & 0.96 \\
\hline $95 \% \mathrm{CI}$ & $178.5-428.9$ & $179.5-431.42$ & $181.35-432.45$ & $30-70$ & $45-72$ & $36-62$ & $2-5$ & $3-8$ & $5.5-11.3$ \\
\hline
\end{tabular}

(b)

\begin{tabular}{ccccccc}
\hline Descriptive characteristics & \multicolumn{3}{c}{ Rainfall volume $(\mathrm{mm})$} & \multicolumn{3}{c}{ Linear retreat } \\
\hline & Pre Monsoon & Monsoon & Post Monsoon & Pre Monsoon & Monsoon & Post Monsoon \\
Mean & 18983.273 & 88761.918 & 46432.609 & 37.67 & 82.00 & 27.67 \\
Standard error & 1494.229 & 6998.748 & 3635.588 & 6.35 & 4.65 & 4.23 \\
Standard deviation & 5176.161 & 24244.373 & 12594.046 & 21.99 & 16.10 & 14.65 \\
Kurtosis & -0.042 & -0.040 & -0.042 & -0.30 & 0.08 & -1.06 \\
Skewness & 0.058 & 0.060 & 0.060 & 0.95 & -0.48 & 0.37 \\
95\% CI & $29108.8-12114.53$ & $136334.2-56582.08$ & $71081.39-29808.32$ & $12-80$ & $49-105$ & $7-52$ \\
\hline
\end{tabular}




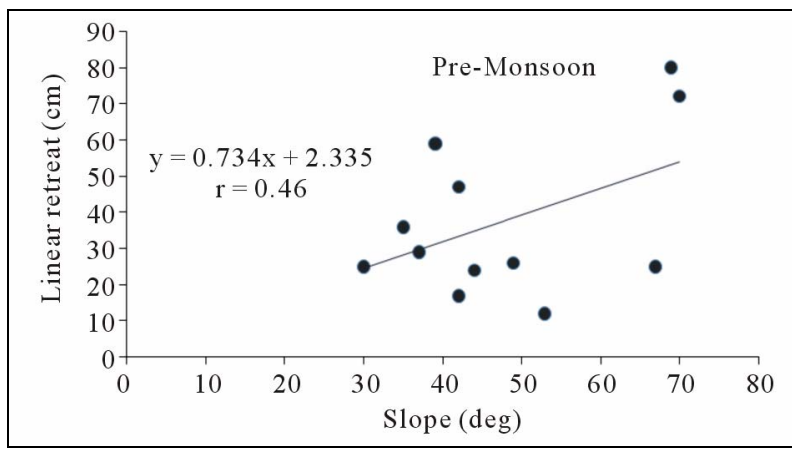

(a)

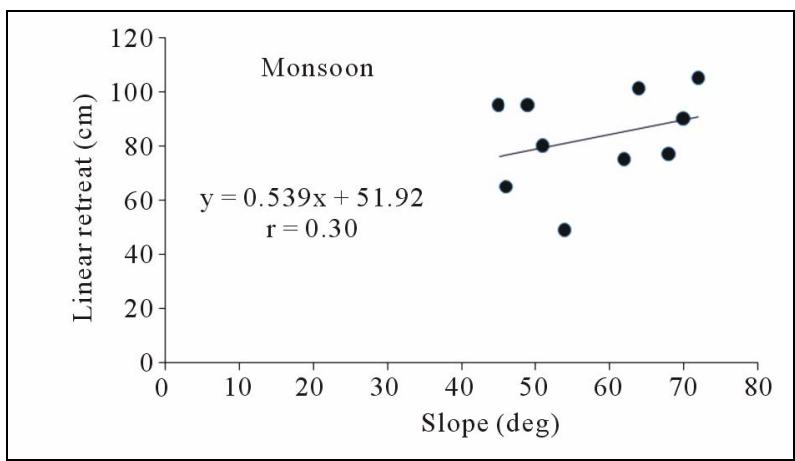

(b)

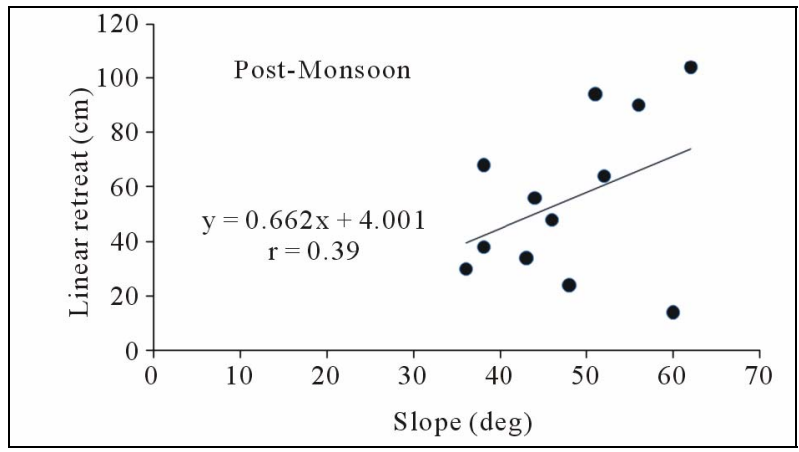

(c)

Figure 6. Correlations of linear gully head retreat and slope gradient. (a) Pre-monsoon; (b) Monsoon; (c) Post-monsoon period.

period the rainfall volume is ranged from $12114.528 \mathrm{~cm}^{3}$ to $29108.802 \mathrm{~cm}^{3}(18983.273 \pm 5176.161)$, in the monsoon period it is ranged from $56582.078 \mathrm{~cm}^{3}$ to $136334.209 \mathrm{~cm}^{3}(88761.917 \pm 24244.372)$, and the rainfall volume is varied from $29808.324 \mathrm{~cm}^{3}$ to 71081.389 $\mathrm{cm}^{3}(46432.608 \pm 12594.045)$ in the post monsoon period. Furthermore, the average linear retreats of gully head in the study area are $37.67 \mathrm{~cm}, 82.00 \mathrm{~cm}$ and $27.67 \mathrm{~cm}$ respectively. The results also illustrated that maximum linear retreat was found during the monsoon period, because of high volume of rainfall intensity. Earlier report also suggested that raindrop impact initiates detachment of soil particles and causes crust formation which sills the surface and limits the infiltration $[30,31]$.

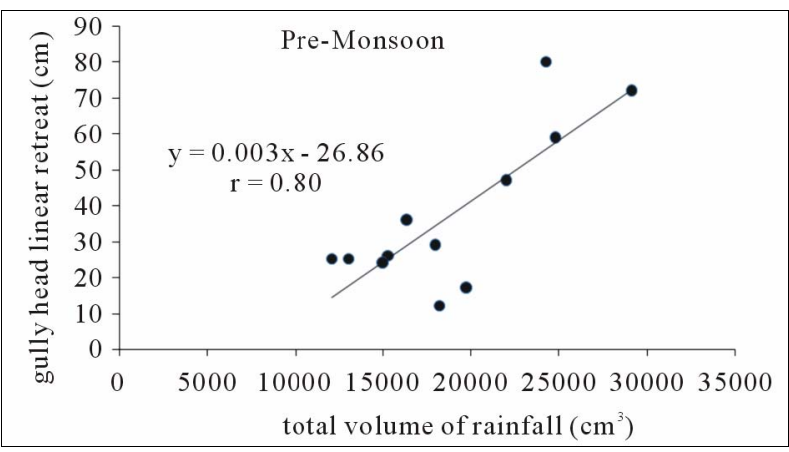

(a)

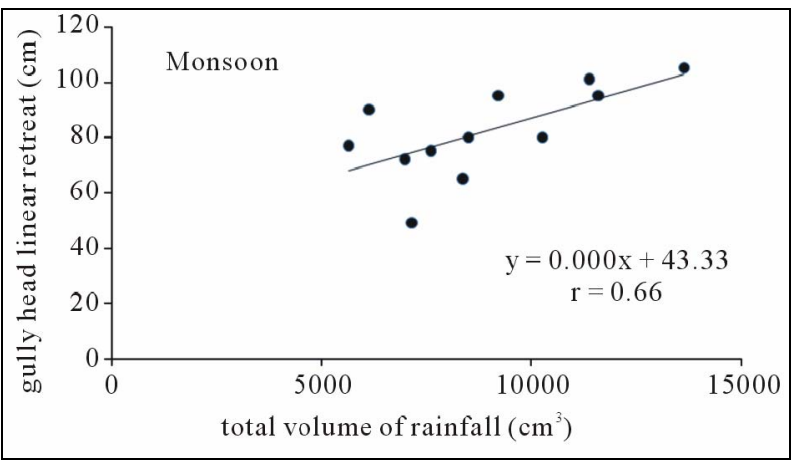

(b)

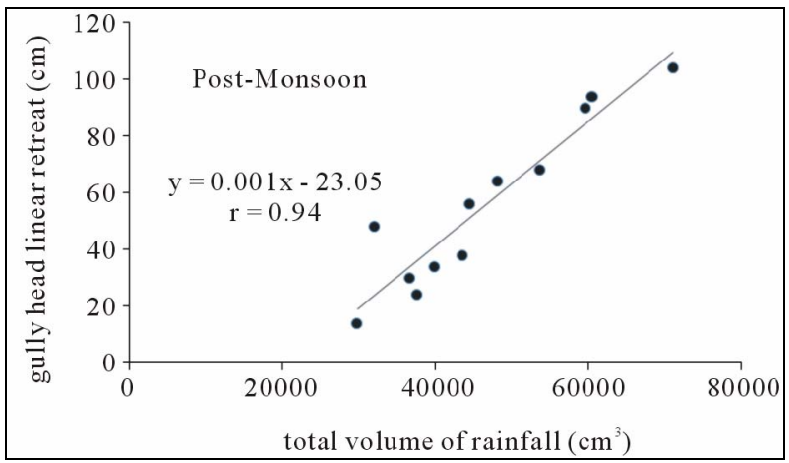

(c)

Figure 7. Correlations of linear gully head retreat and rainfall. (a) Pre-monsoon; (b) Monsoon; (c) Post-monsoon period.

However, a simple linear relationship was calculated between the rainfall volume and gully head retreat, which showed strong positive and significant relationship in the pre monsoon $(\mathrm{r}=0.80, \mathrm{p}<0.001)$, monsoon $(\mathrm{r}=0.66, \mathrm{p}$ $<0.001)$, and post monsoon period $(\mathrm{r}=0.94, \mathrm{p}<0.001)$. Carey (2006) suggested that both intense rainfall and low flow under protracted wet soil may prompt troubles of gully growth that may generate spoil to drainage lines if not secluded. Hence, gully development is a function of numerous factors out of which rainfall is a prime reason.

Furthermore, a comparison has been made between the cumulative gully head retreat and rainfall intensity in the study area (Table 1(b) and Figure 8). Rainfall intensity was calculated by collecting the rainfall within each 


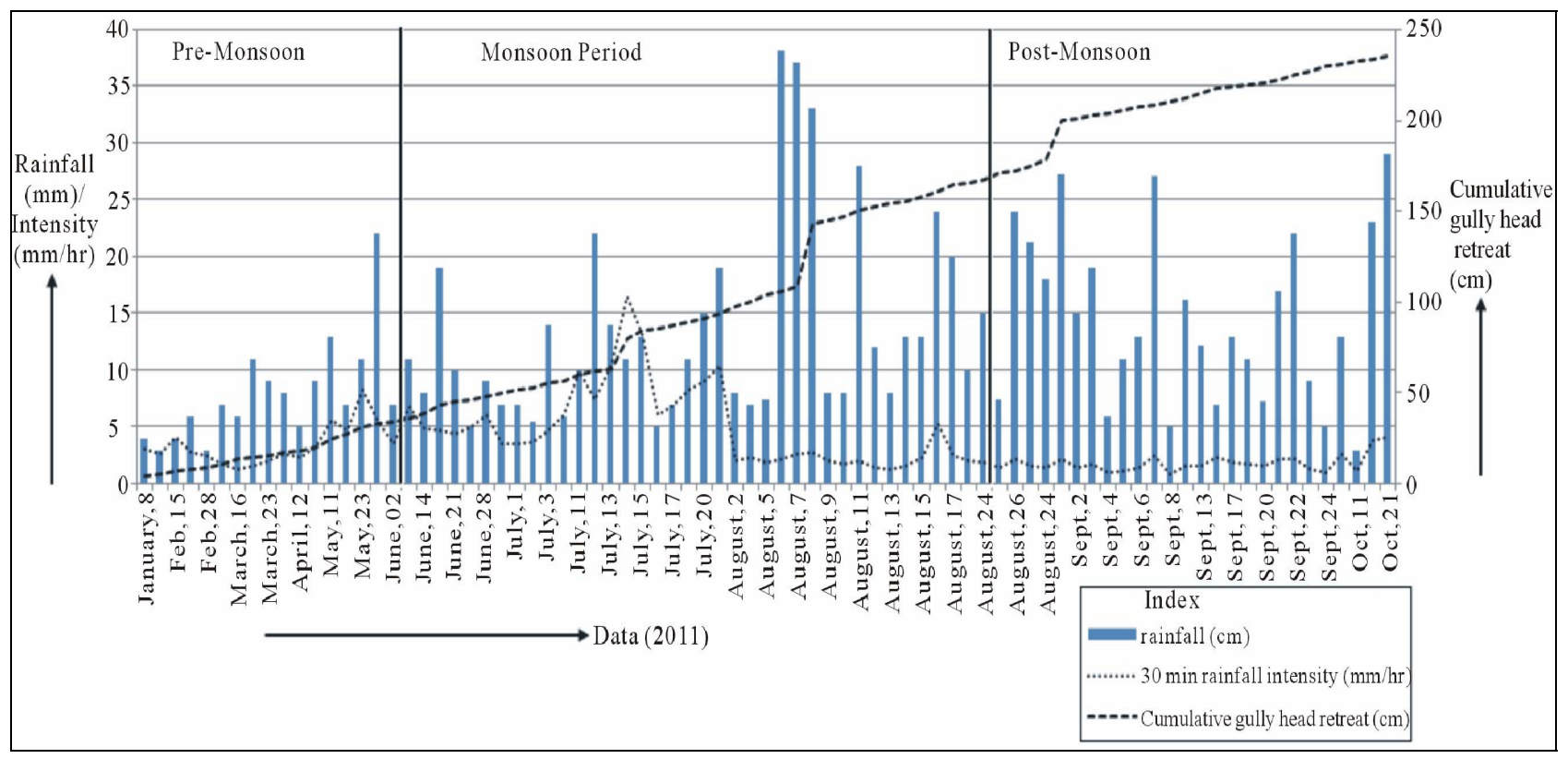

Figure 8. Relation between rainfall and cumulative linear gully head retreat.

gully area for 30 minutes. Result of the analysis showed that rainfall intensity was maximum in monsoon period in relation to pre monsoon and post monsoon period. Results also illustrated that due to increase in rainfall intensity, subsidence and slumping occurred in the mid-monsoon ( $7^{\text {th }}$ August, 2011) and end of the monsoon period $\left(26^{\text {th }}\right.$ August, 2011) in the study area. Conversely, no any significant relationship was established between the rainfall intensity and gully head retreat $(\mathrm{r}=0.06)$, suggested that the influence of rainfall intensity is not affected by the gully erosion. It may be due to the reason of duration rainfall that may affect the shear stress between the soil particles, and finally the runoff has taken place and aids to detach the soil. The ephemeral gully formation results from accelerated erosion, and therefore unhinged landscape.

\subsection{Vegetation Coverage vs. Gully Head Retreat}

In the study area, attention has also been focused on the possessions of below ground biomass on gully erosion, since conventionally all the studies on vegetation cover put importance on above-ground biomass [32,33]. During the pre-monsoon, monsoon and post-monsoon the average percentages of vegetation cover were $3.21 \%$, $4.92 \%$ and $7.73 \%$ respectively (Table $\mathbf{1}(\mathbf{a})$ ). However, the correlation coefficient between the linear retreat of gully head and percent of vegetation cover is illustrated the weak relationship in pre-monsoon $(\mathrm{r}=0.17)$, in monsoon $(\mathrm{r}=0.14)$, and in the post-monsoon season $(\mathrm{r}=$ 0.19 ) respectively. It may be due to the reason of more important roles played by high rainfall, and steep slope in gully head retreat in this particular area.

\subsection{Gully Head Erosion vs. Runoff-Contributing Area (RCA)}

In the present work, a correlation was drawn between the RCA and linear retreat of gully head. Like previous analysis, the relationship was drawn separately in the pre-monsoon, monsoon and post-monsoon period (Figure 9). Gully head morphology is the key factor of gully head erosion. However, the morphological characteristics of gully heads and its area are shown in Table 2. Moreover, the relationship is much stronger in the pre monsoon $(\mathrm{r}=0.80, \mathrm{p}<0.001)$ and post monsoon period $(\mathrm{r}=$ $0.94, \mathrm{p}<0.001)$ in respect to the monsoon period $(\mathrm{r}=$ $0.66, \mathrm{p}<0.001)$. We also observed that the overall retreat of gully head had very strong and positive relationship with the RCA $(r=0.89, p<0.001)$. The result is also corroborated with the previous study [34-36]. It may be due to the effect of huge volume of soil loss from these gully slopes be prejudiced by the upslope contribution of runoff and sediment.

\subsection{Seasonal Influence of Gully Head Retreat}

The gully head retreat in different season is shown in Figure 10. In the study area, maximum gully erosion is observed in the monsoon period $(55.67 \%)$. It may be due to the high rainfall input. However, the minimum gully erosion is examined in the post-monsoon season (18.78\%). In the pre-monsoon season, the gully head retreat ranges from $12-80 \mathrm{~cm}$, in monsoon period it is varied from 49 $105 \mathrm{~cm}$, and in the post-monsoon period, the value of retreat is varied from $7-52 \mathrm{~cm}$. 


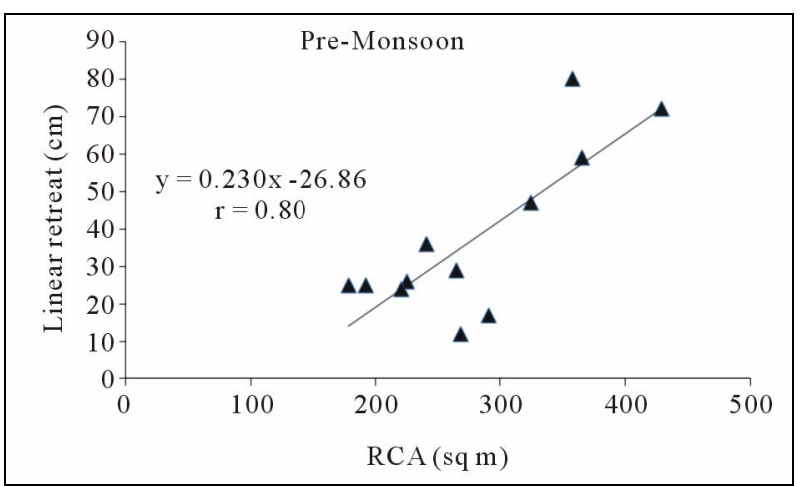

(a)

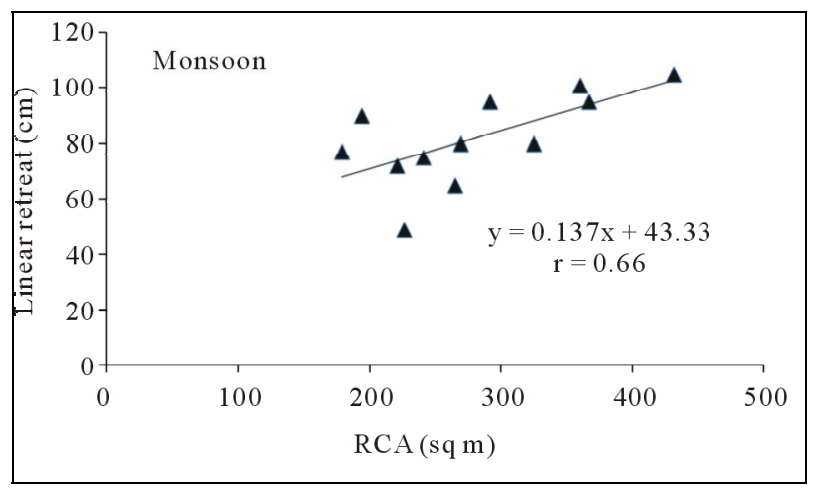

(b)

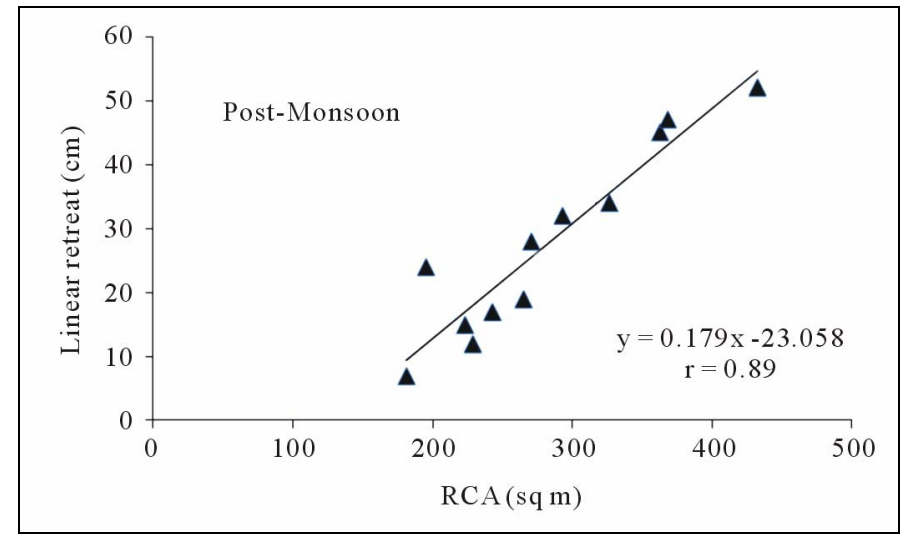

(c)

Figure 9. Correlations linear gully head retreat and runoff contributing area (RCA). (a) Pre-monsoon; (b) Monsoon; (c) Post-monsoon period.

Table 2. Morphological characteristics of gully heads, catchments area and gully head retreat.

\begin{tabular}{|c|c|c|c|c|}
\hline Gully heads & Major gullying process & $\begin{array}{l}\text { Runoff contributing } \\
\text { Area }\left(\mathrm{m}^{2}\right)\end{array}$ & $\begin{array}{l}\text { Mean slope } \\
\text { (degree) }\end{array}$ & $\begin{array}{l}\text { Total gully head retreat } \\
\text { during January-Oct., } 2011(\mathrm{~cm})\end{array}$ \\
\hline G-1 & Overland flow & 270.63 & 49.33 & 120 \\
\hline G-2 & Overland flow, undercutting & 292.95 & 46.33 & 144 \\
\hline G-3 & Overland flow, undercutting & 195.3 & 61.00 & 139 \\
\hline G-4 & Overland flow, undercutting, landsliding & 362.7 & 63.00 & 226 \\
\hline G-5 & Overland flow, undercutting, landsliding and Piping & 432.45 & 68.00 & 229 \\
\hline G-6 & Overland flow & 368.28 & 46.33 & 201 \\
\hline G-7 & Overland flow, undercutting, subsidence & 326.43 & 43.66 & 161 \\
\hline G-8 & Overland flow, undercutting & 242.73 & 46.66 & 128 \\
\hline G-9 & Overland flow, undercutting & 265.08 & 40.30 & 113 \\
\hline G-10 & Overland flow, undercutting and piping & 228.78 & 50.50 & 87 \\
\hline G-11 & Overland flow & 181.35 & 52.60 & 109 \\
\hline G-12 & Overland flow & 223.2 & 47.00 & 111 \\
\hline
\end{tabular}




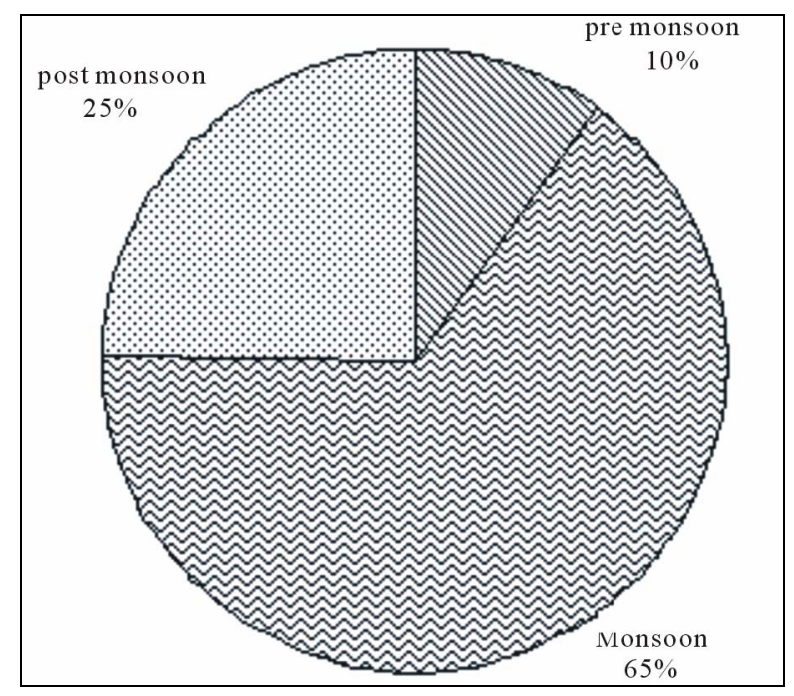

Figure 10. Gully head erosion during pre-monsoon, monsoon and post monsoon periods.

\section{Conclusion}

Gully head progression is conceived as current danger for land degradation. Therefore, monitoring the growth rate of gullies and understanding the factors for gully extension are important for land resource managers. Field observations showed geomorphic differences between the gully channels. The favourable environment for gully and rill development arises when soil is unguarded by vegetation and crusting. Taking account of fluvial development of gully channels, the linear shaped gullies are measured to have been preferentially formed by knickpoint movement escorted by a lowering process, and this can be a swaying cause for the hasty headcut retreat. Retreat of gully head is maximum in the monsoon season. Our analysis also showed that the slope, rainfall and runoff contributing area have a strong a positive relationship with the gully erosion in Paschim Medinipur district. Under extreme concentrated rainfall, gully erosion is the foremost cause of sediment at the catchment scale.

\section{Acknowledgements}

We express our profound heartfelt thanks to M. M. Maiti, R. K. Bhattachryay, N. Sar, R. Sahoo, R. K. Ghosh ,K. Risi, P. Maiti, M. K. Jana, A. K. Jana, S. Jana, C. Kandar, S. Mandal, D. Mandal, K. K. Das, T. K. Ghosh, D. Patra, U. Palui, M. Das, S. Mondal, S. Pal, P. Sarkar, S. Ghosh, for their constant help and cooperation during the field study.

\section{REFERENCES}

[1] L. J. Vandekerckhove, J. Poesen and G. Govers, "MidTerm Gully Headcut Retreat Rates in Southeast Spain
Determined from Aerial Photographs and Ground Measurements," Catena, Vol. 50, No. 2-4, 2003, pp. 329-352. doi:10.1016/S0341-8162(02)00132-7

[2] P. Billi and F. Dramis, "Geomorphological Investigation on Gully Erosion in the Rift Valley and the Northern Highlands of Ethiopia," Catena, Vol. 50, No. 2-4, 2003, pp. 353-368. doi:10.1016/S0341-8162(02)00131-5

[3] J. De Vente, J. Poesen and G. Verstraeten, "The Application of Semi-Quantitative Methods and Reservoir Sedimentation Rates for the Prediction of Basin Sediment Yield in Spain," Journal of Hydrology, Vol. 305, No. 1-4, 2005, pp. 63-86. doi:10.1016/j.jhydrol.2004.08.030

[4] C. Valentin, J. Poesen and Y. Li, "Gully Erosion: Impacts, Factors and Control," Catena, Vol. 63, No. 2-3, 2005, pp. 132-153. doi:10.1016/j.catena.2005.06.001

[5] B. Carey, "Gully Erosion, Fact Sheet-L81, Natural Resources Sciences. Department of Natural Resources and Water," The State of Queensland, No. QNRMO5374, 2006.

[6] R. J. Wasson, G. Caitcheon, A. S. Murray, M. McCulloch and J. Quade, "Sourcing Sediment Using Multiple Tracers in the Catchment of Lake Argyle, Northwestern Australia," Environmental Management, Vol. 29, No. 5, 2002, pp. 634-646. doi:10.1007/s00267-001-0049-4

[7] J. Poesen, J. Nachtergaele, G. Verstraeten and C. Valentin, "Gully Erosion and Environmental Change: Importance and Research Needs," Catena, Vol. 50, No. 2-4, 2003, pp. 91-133. doi:10.1016/S0341-8162(02)00143-1

[8] S. Huon, B. Bellanger, P. Bonté, S. Sogon, P. Podwojewski, C. Girardin, C. Valentin, A. de Rouw, F. Velasquez, J. P. Bricquet and A. Mariotti, "Monitoring Soil Organic Carbon Erosion with Isotopic Tracers: Two Case Studies on Cultivated Tropical Catchments with Steep Slopes (Venezuela, Laos)," Soil Erosion and Carbon Dynamics Advances in Soil Science, 2005, pp. 301-328.

[9] R. R., Wells, C. V. Alonso and S. J. Bennett, "Morphodynamics of Headcut Development and Soil Erosion in Upland Concentrated Flows," Soil Science Society of America Journal, Vol. 73, No. 2, 2009, pp. 521-530. doi:10.2136/sssaj2008.0007

[10] W. E. Dietrich and T. Dunne, "The Channel Head," In: K. Beven and M. J. Kirkby, Eds., Channel Network Hydrology, John Wiley, New York, 2005, pp. 175-219.

[11] S. K. Ghimire, D. Higaki and T. P. Bhattarai, "Gully Erosion in the Siwalik Hills, Nepal: Estimation of Sediment Production from Active Ephemeral Gullies," Earth Surface Processes and Landforms, Vol. 31, No. 2, 2006, pp. 155-165. doi:10.1002/esp.1320

[12] D. J. Oostwoud Wijdenes1 and R. Bryan, "Gully-Head Erosion Processes on a Semi-Arid Valley Floor in Kenya: A Case Study into Temporal Variation and Sediment Budgeting," Earth Surface Processes and Landforms, Vol. 26, No. 9, 2001, pp. 911-933. doi:10.1002/esp.225

[13] R. Menéndez-Duarte, J. Marquínez, S. Fernandez-Menéndez and R. Santos, "Incised Channels and Gully Erosion in Northern Iberian Peninsula: Controls and Geomorphic Setting," Catena, Vol. 71, No. 2, 2007, pp. 267-278. doi:10.1016/j.catena.2007.01.002

[14] D. R. Montgomery, "Erosional Processes at an Abrupt 
Channel Head: Implications for Channel Entrenchment and Discontinuous Gully Development," In: S. E. Darby and A. Simon, Eds., Incised River Channels: Processes, Forms, Engineering and Management, John Wiley, New York, 1999, pp. 247-276.

[15] D. R. Montgomery and W. E. Dietrich, "Source Areas, Drainage Density and Channel Initiation," Water Resources Research, Vol. 25, No. 8, 1989, pp. 1907-1918. doi:10.1029/WR025i008p01907

[16] D. R. Montgomery and W. E. Dietrich, "Channel Initiation and the Problem of Landscape Scale," Science, Vol. 255, No. 5046, 1992, pp. 826-830. doi:10.1126/science. 255.5046 .826

[17] D. J. Oostwoud-Wijdenes, J. Poesen, L. Vandekerckhove, J. Nachtergaele and J. De Baerdemaeker, "Gully-Head Morphology and Implications for Gully Development on Abandoned Fields in a Semiarid Environment, Sierra Da Gata, Southeast Spain," Earth Surface Processes and Landforms, Vol. 24, No. 7, 1999, pp. 585-603. doi:10.1002/(SICI)1096-9837(199907)24:7<585::AID-ES P976>3.0.CO;2-\#

[18] D. J. Oostwoud-Wijdenes, J. Poesen, L. Vandekerckhove and M. Ghesquiere, "Spatial Distribution of Gully Head Activity and Sediment Supply along Anephemeral Channel in a Mediterranean Environment," Catena, Vol. 39, No. 3, 2000, pp. 147-167. doi:10.1016/S0341-8162(99)00092-2

[19] W. L. Graf, "The Rate Law in Fluvial Geomorphology," American Journal of Science, Vol. 277, No. 2, 1977, pp. 178-191. doi:10.2475/ajs.277.2.178

[20] A. C. Imeson and F. J. P. M. Kwaad, "Gully Types and Gully Prediction,” Geografisch Tijdschrift, Vol. 14, No. 5, 1980, pp. 430-441.

[21] M. A. Nearing, G. R. Foster, L. J. Lane and S. C. Finkner, "A Process-Based Soil Erosion Model for USDA-Water Erosion Prediction Project," Transactions of the American Society of Agricultural Engineers, Vol. 32, No. 5, 1989, pp. 1587-1593.

[22] A. P. J. De Roo, C. G. Wesseling and C. J. Ritsema, "LISEM: A Single Event Physically-Based Hydrologic and Soil Erosion Model for Drainage Basins. I: Theory Input and Output," Hydrological Processes, Vol. 10, No. 8, 1996, pp. 1107-1117. doi:10.1002/(SICI)1099-1085(199608)10:8<1107::AIDHYP415>3.0.CO;2-4

[23] R. P. C. Morgan, J. N. Quinton, R. E. Smith, G. Govers, J. W. A. Poesen, K. Auerswald, G. Chisci, D. Torri and M. E. Styczen, "The European Soil Erosion Model (EUROSEM): A Dynamic Approach for Predicting Sediment Transport from Fields and Small Catchments," Earth Surface Processes and Landforms, Vol. 23, No. 6, 1998, pp. 527-544.

doi:10.1002/(SICI)1096-9837(199806)23:6<527::AID-ES P868>3.0.CO;2-5

[24] S. Bandyopadhyay, "Drainage Evolution in Badland Terrain at Gangani in Medinipur District, West Benagl," Geographical Review of India, Vol. 50, No. 3, 1988, pp. 10-20.
[25] P. K. Shit and R. K. Maiti, "Mechanism of Gully-Head Retreat-A Study at Ganganir Danga, Paschim Medinipur, West Bengal," Ethiopian Journal of Environmental Studies and Management, Vol. 5, No. 4, 2012, pp. 332342.

[26] A. M. Michael and T. P. Ojha, "Principles of Agricultural Engineering," MIS Join Brothers, New Delhi, 2006, pp. 331-390.

[27] D. Wijdenes, G. Gyssels, L. Beuselinck and E. de Luna, "Characteristics and Controlling Factors of Bank Gullies in Two Semiarid Mediterranean Environments," Geomorphology, Vol. 33, No. 1-2, 2000, pp. 37-58. doi:10.1016/S0169-555X(99)00109-9

[28] A. N. Samani, H. Ahmadi, M. Jafari, G. Boggs, J. Ghoddousi and A. Malekian, "Geomorphic Threshold Conditions for Gully Erosion in Southwestern Iran (BoushehrSamal Watershed)," Journal of Asian Earth Sciences, Vol. 35, No. 2, 2009, pp. 180-189. doi:10.1016/j.jseaes.2009.02.004

[29] R. R. Wells, S. J. Bennett and C. V. Alonso, "Modulation of Headcut Soil Erosion in Rills Due to Upstream Sediment Loads," Water Resources Research, Vol. 46, No. 12, 2010, pp. 2-16. doi:10.1029/2010WR009433

[30] P. I. A. Kinnell, "Raindrop Impact Induced Erosion Processes and Prediction: A Review," Hydrological Process, 2004. http://members.ozemail.com.au-/ pkinnell/RIIEPP.pdf

[31] S. Jebari, R. Berndtsson, A. Bahri and M. Boufaroua, "Exceptional Rainfall Characteristics Related to Erosion Risk in Semiarid Tunisia," The Open Hydrology Journal, Vol. 1, 2008, pp. 25-33. doi: $10.2174 / 1874378100802010025$

[32] G. Gyssels, J. Poesen, E. Bochet and Y. Li, "Impact of Plant Roots on the Resistance of Soils to Erosion by Water: A Review," Progress in Physical Geography, Vol. 29, No. 2, 2005, pp. 189-217. doi:10.1191/0309133305pp443ra

[33] S. De Baets, J. Poesen, A. Knapen and P. Galindo, "Impact of Root Architecture on the Erosion-Reducing Potential of Roots during Concentrated Flow," Earth Surface Processes and Landforms, Vol. 32, No. 9, 2007, pp. 1323-1345. doi:10.1002/esp.1470

[34] C. Qiangguo, "Effect of Runoff and Sediment from Hillslope on Gully Slope in the Hilly Loess Region, North China," In: D. E. Stott, R. H. Mohtar and G. C. Steinhardt, Eds., The 10th International Conservation Organization Meeting, West Lafayette, 24-29 May 1999, pp. 732-736. http://topsoil.nserl.purdue.edu/nserlweb-old/isco99/pdf/IS COdisc/SustainingTheGlobalFarm/P179-QG\%20Cai.pdf

[35] J. L. Bull and J. M. Kirkby, "Channel Heads and Channel Extension,” In: L. J. Bull and M. J. Kirkby, Eds., Dryland River: Hydrology and Geomorphology of Semi-Arid Channels, Wiley, Chichester, 2002, pp. 263-287.

[36] P. K. Shit and R. K. Maiti, "Rill Hydraulics-An Experimental Study on Gully Basin in Lateritic Upland of Paschim Medinipur, West Bengal, India," Journal of Geography and Geology, Vol. 4, No. 4, 2012, pp. 1-11. doi:10.5539/jgg.v4n4p1 